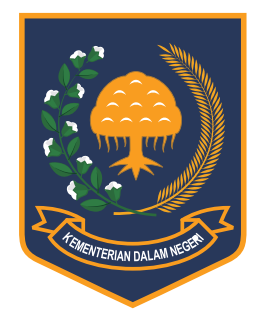

Jurnal Bina Praja 9 (1) (2017): 159-169

Jurnal Bina Praja

e-ISSN: 2503-3360 | p-ISSN: 2085-4323

Accreditation Number

735/AU2/P2MI-LIPI/04/2016

http://jurnal.kemendagri.go.id/index.php/jbp/index

\title{
THE ROLE OF REgIONAL GOVERNMENT \\ in Growing Small and Medium EnTERPRises' Performance TOWARDS CREATIVE INDUSTRY IN JAMBI PROVINCE
}

\author{
Susi Desmaryani * \\ Regional Research and Development Agency (Balitbangda) Jambi Province \\ Jl. R.M. Noor Admadibrata No. 1A
}

Received: 1 April 2017; Accepted: 13 May 2017; Published online: 31 May 2017

DOI: $10.21787 /$ jbp.09.2017.159-169

\begin{abstract}
Globalization requires Small and Medium enterprises to increase its existence in order to compete in a global world. Small and Medium enterprises have to always increase the creativity to be able to create products that have innovated. Yet currently, SMEs still have obstacles in increasing its existence, such as the poor ability of businesses, the difficulty of access to capital and does not quickly follow the development of science and technology. The purpose of this study is to determine the role of government to grow the performance of SMEs towards creative industry in Jambi Province. The sampling technique for the location and respondents is in a purposive sampling. The provision of sample site and respondents selection is based on the already defined criteria. For locations, there are 7 (seven) locations selected as the samples and 200 for the sample of respondents. The analysis method used is the descriptive analysis depicting government role in improving SMEs performance. The results of the study explain that the government's support is still low to improve the quality of human resources through education and training. There are still SMEs which have never attended the training because the Department of Industry and Trade has not had a database of SMEs which have attended the training or not. SMEs still have capital problems. The government is not yet optimally introducing technological advances and not yet optimally assisting the development and marketing of products. There is overlapping of the same programs among SKPD that empower SMEs. From the other side, the business climate is already conducive as the government gives ease of permit and smoothness of business. The results of the study recommend (1) to provide education and training equally for SMEs (2) Creation of synergistic between the related SKPD and SMEs (3) Developing microfinance institution to solve the capital problem (3) Jambi Provincial Government needs to build cooperation with universities to do Transfer of science and technology.
\end{abstract}

Keywords: Performance, SMEs, and Creativity

\section{INTRODUCTION}

The role of government in improving the performance of Small and Medium Industry has been regulated in Law Number 20 of 2008. However, the growth of SMEs is still experiencing problems, that it is rarely able to survive. It is as if the Small and Medium Industries give the impression of being easy to lose and easy to grow, but for the sake of business, it is difficult to maintain. The inhibiting factor that causes SMEs difficult to grow is the ability of MSMEs themselves, especially in maintaining product quality, unable to keep up with technological developments, difficult to find markets, and is difficult in obtaining capital. This has been proven by the results of research conducted by Sudiarta, Kirya, \& Cipta (2014) on SMEs difficulties in Bengli in improving its performance, which is access to capital, technology, business ability, and marketing. Maryati (2012) also explained that the circumstances that cause SMEs rarely able to survive and hard to grow are due to low public interest in entrepreneurship. Meanwhile, the competition of creative economy era now requires SMEs which have high creativity and morale by exploiting existing resources at SMEs so that they are able to create unique and different products, and have selling value in the market.

\footnotetext{
* Corresponding Author

Phone : +6281312453338

Email : Susidesmaryani@yahoo.com
} 
Table 1.

Creative Industries Contribution to Handicraft, Fashion, and Culinary Sectors to GDP Growth and Employment Absorption in Province

\begin{tabular}{clcccc} 
No. & $\begin{array}{c}\text { Industrial } \\
\text { Group }\end{array}$ & Employment & $\begin{array}{c}\text { Investment } \\
\text { Value } \\
\text { (IDR000) }\end{array}$ & $\begin{array}{c}\text { Production } \\
\text { Value } \\
\text { (IDR000) }\end{array}$ & $\begin{array}{c}\text { Contribution } \\
\text { to GDP (\%) }\end{array}$ \\
\hline 1. & Handicraft & 15,437 & $179,987,660.5$ & $130,040,984$ & 9.008 \\
\hline 2. & Fashion & 2,420 & $8,506,415.5$ & $25,103,490$ & 5.645 \\
\hline 3. & Culinary & 7,412 & $28,594,689$ & $87,727,064$ & 5.626 \\
\hline
\end{tabular}

Source: Peindag (Data Processed in 2015)

The results of Uchegbulam et al.'s research (2015) states that creativity is the capital of SMEs to create innovation and get market and it is supported by research result by Ismail et al. (2014) which explains that SMEs in Malaysia have creativity so as to create innovative products to gain market share and strengthening the existence of SMEs themselves. Therefore, it is expected that the existing SMEs in the province of Jambi grow into creative SMEs which take advantage of ideas or creativity that exist to create products that have uniqueness and differences.

Small and Medium Industry in Jambi Province is part of small and medium business group (UMKM). Currently, the Jambi provincial government has not conducted the Grouping of creative SMEs, the industry indicator is said to be creative if the industry is able to create value-based ideas based on creativity of human resources (creatives) and based on the utilization of science, including cultural heritage and technology. The main resource in the creative industry is creativity that is defined as the capacity or ability to produce or create something unique, creating solutions of a problem or doing something different (Ministry of Economy and Tourism, 2014).

SMEs challenges in Jambi Province to grow into creative SMEs requires creativity, in order to be able to produce products that have differences with competitors' products. Currently, there are not many SMEs with creative behavior, especially in handicraft, culinary, and fashion sectors, whereas these three sectors give the biggest contribution in Jambi Province, as described in Table 1.

Based on Table 1, the biggest contribution to GRDP is the handicraft sector by $9.00 \%$, followed by the fashion sector by $5.645 \%$, and the culinary sector by $5.626 \%$. If seen from the amount of contribution to the GRDP of the three sectors, they will affect the economic growth of Jambi Province, especially on the absorption of labor so the unemployment rate will be reduced.
However, Small and Medium Enterprises (SMEs) in the handicrafts, fashion, and culinary sectors still experience some problems. In this case, small and medium industry groups (SMEs) of Jambi province have not lead to the availability of creative human resources as they still have problems in Human Resources that are not qualified. It is proven that the marketing results of the industry, for now, can be said still around the Jambi province, which means the largest percentage of products for now only consumed by Jambi society. Only 3\% of SMEs already have marketing outside Indonesia such as handicraft bags, and batik while the other $97 \%$ still survive in the domestic market, because they have not been export-oriented so that SMEs in Jambi Province have not been able to penetrate the international market (Industry, 2013, to date). Supported by a research result by Wuryandani \& Meilani (2013), there is still a limitation of exportoriented SMEs because of low ability to access market information, export management competence, and export promotion that is still lacking.

Along with advances in technology and science, it colors the changes in consumer tastes. Consumer behavior in consuming goods and services showed an increase in the level of standard needs; consumers always want the ease and benefits of products that can solve problems faced by consumers. Currently ASEAN market is a threat to SMEs group in Jambi Province, especially in handicraft, culinary, and fashion sectors, but ASEAN market also provides big opportunity. Opportunities can be achieved if the SMEs are able to compete with competitors' products. For that, the emphasis on creativity to produce products that have innovation is the right answer to master the ASEAN market.

The result of Indarti \& Anton's study (2014) explains that Indonesia is not ready to enter Asean Economy Community (AEC) as there are many things that still become homework, such as lack of infrastructure, low quality of human resources, and the regulations that are counter-productive. 
The ASEAN market provides an opportunity for Indonesia to have a wider market, not just the market within the country. It is conceivable that the current ASEAN market is closely linked to Human resources creating products that can compete with imported products. Therefore, the role of government as facilitator, regulator, and catalyst can be very important to develop creativity among micro, small, and medium enterprises so that business actors can survive, grow, and develop.

The low impact of government support through the function of facilitators, regulators and catalysts has caused SMEs in Jambi province to survive but not yet growth-oriented. Currently, SMEs in Jambi Province also have a capital problem to strengthen their existence. The difficulty in getting capital makes SMEs unable to grow. Therefore, the role of government is needed to improve the performance of SMEs by providing support to SMEs, especially to facilitate access to capital (Sudiarta et al., 2014). The difficulty in obtaining financing is one of the reasons because the SMEs still do not have a bank account yet and it becomes a common problem, supported by the inability of business actors to provide collateral. The research by Harash, Al-Timimi, \& Alsaadi (2014) found that business actors are unable to receive financing from financial institutions, in this case, bank, due to the inability to give collateral, which has an impact on the growth of SMEs.

The result of research by Wuryandani \& Meilani (2013) also explains that MSMEs tend to not develop because of lack of government support in terms of financing, even often out of business or just change the type of business in accordance with the current market trend to survive. The difficulty of accessing capital, low quality of human resources, and support from the government is the decisive factor to compete in the global market. The terms to be able to export is that SMEs should have a product of market interest, both in the ASEAN market and world market. The ability to create market-favored products is closely linked to human resource capabilities. The process of cultivating entrepreneurs into tough entrepreneurs, which are entrepreneurs who have creative and innovative behavior, is one of the tasks of the government as mandated in Law Number 20 of 2008, where the government, through its role, must strive to build the ability of SMEs to have a good performance.

Based on the problems faced by the small and medium industry groups that have been described, the purpose of this study is to know: How the role of local government in improving the performance of Small and Medium Industry to Creative Industry. The Role and support from the government are needed by SMEs so that SMEs can solve the problem so as they can grow and develop. These problems include the inability to face invasion of changes in consumer tastes that are dynamic, and competition with competitors that increasingly stringent. Therefore, the government through the Law Number 20 of 2008 continues to empower SMEs in order for SMEs to be able to develop internal strength in the form of a strategy to compete. According to the Ministry of Tourism and Creative Economy (2014), it explains that the development of industries that are competitive, growing, and diverse is a strategy to compete in the midst of today's global market. Therefore, industry must be able to build cooperation network with suppliers and consumers. SMEs must have the knowledge to recognize consumer behavior by having the ability to recognize the changing of consumer taste, to know the change of market, so that SMEs are able to make products with standard and in accordance with the changing of consumer taste. Thus, Raliby, Rusdjijati, \& Prabowo (2013) explain that to maintain the continuity and the competitiveness of industries in Indonesia, needed an analysis to the products that include design, diversity, and quality.

The role of government through institutional or so-called institutions in the growth of Small and Medium Industries is the backbone or driving force for the success of Small and Medium Industry. The Government through the regulatory of requirements with policies and rules to protect, supervise, encourage, and promote the growth of Small and Medium Industry. The government as a facilitator has a role in achieving the objectives of SMEs development to achieve business goals by providing training and funding facilities. And the government as a catalyst helps the development of SMEs, by protecting intellectual property and stimulating the growth of SMEs creativity by giving rewards. The role of SMEs in contributing to economic growth is significant if there is a government policy that supports and helps SMEs to gain access to capital, technological improvement, quality improvement, skills development, and able to dominate domestic and international markets (Ntiamoah, Li, \& Kwamega, 2016).

The role of government through institutions by the Ministry of Tourism and Creative Economy (2014) is an important factor for maintaining the existence of SMEs in the midst of competition. In addition, other institutions that drive the performance of SMEs to create innovation are universities with the transfer of knowledge and transfer of technology to SMEs. Piterou \& Birch (2014) finds that linkages between universities and small businesses through incubators can improve the ability of small businesses to develop product innovation. Thus, the government, through its facilitator function, in collaboration with universities together improve the performance of SMEs.

In addition, the problem of financing is a 


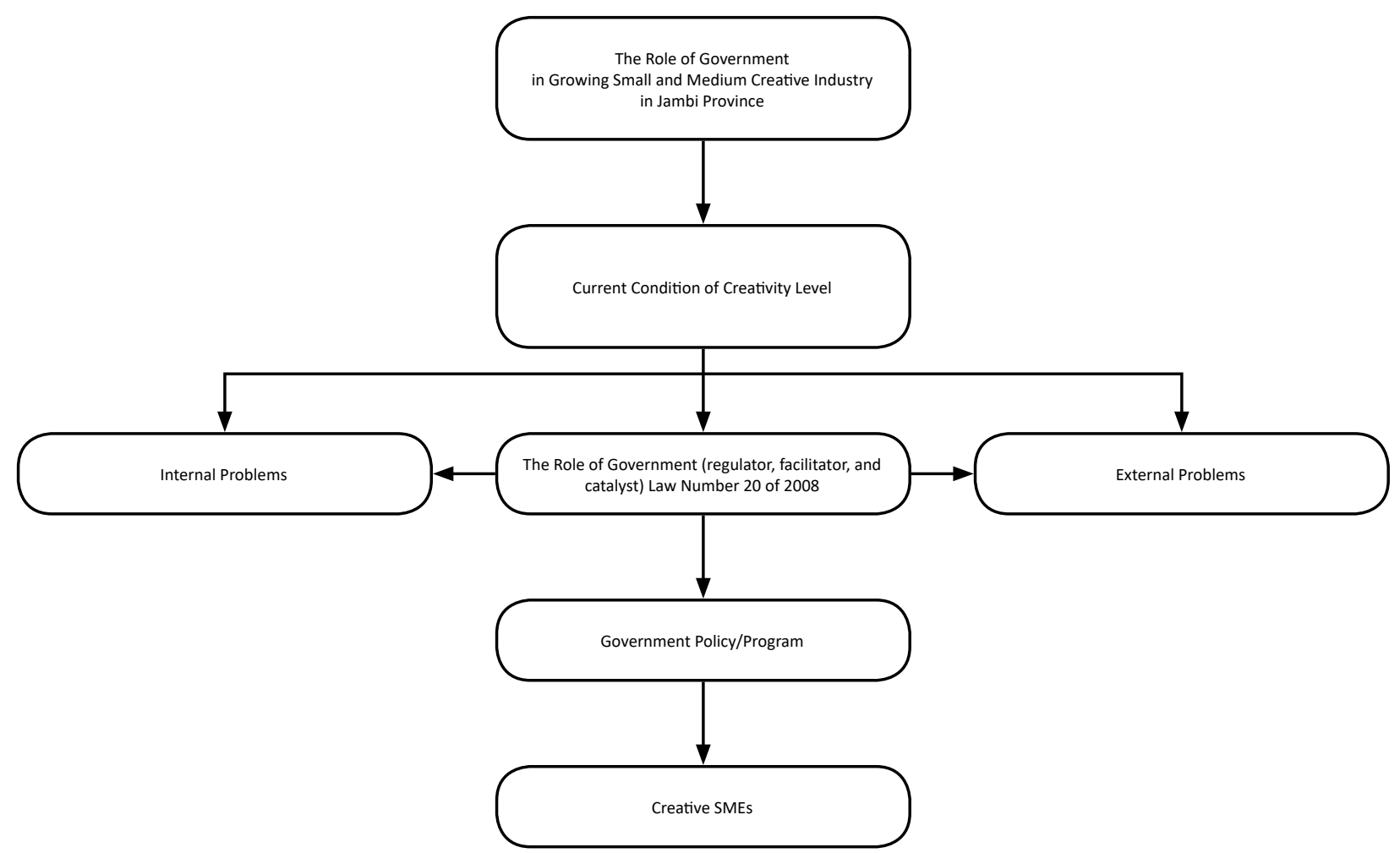

Figure 1. The Role of Government in Growing Creative Industry in Jambi Province

problem that is always faced by Small and Medium Industry groups in general. Innovation requires capital, either from the government, banking, or non-banking institutions. Gjini (2014) stated that SMEs are more dependent on the use of external funds (loans from banks). Debt used for business development if managed properly will affect business growth.

Capital is still a major obstacle for entrepreneurs to expand their business. To gain access to capital from banks, many entrepreneurs have no knowledge of the account that are the requirements of the banking system. Uncertainty over bookkeeping becomes a problem in obtaining financing from banking institutions and non-banking institutions. Small and Medium Industry group are yet to have cable bank, and this is the causing factor for the difficult access of credit to banking institutions. Similarly, financing institutions have the same problem and become the main reason why it is difficult to help develop SMEs through the provision of financing to Small and Medium Industries because (1) the difficulty in assessing the feasible and bankable MSMEs that meet the requirements set in the provision of credit, (2) The low interest of MSMEs in the effort of development conducted by the funding institutions, and (3) Most MSMEs have not yet conducted a financial separation between personal finance and business finance (Ministry of Trade, 2013). Due to the difficulty of access to banking institutions to obtain financing, entrepreneurs use other financing alternatives such as microfinance institutions that conduct savings and loan activities (Quaye \& Sarbah, 2014). Law Number 20 of Article 23 of 2008 also has set the role of government in assisting capital problems and the incapability of SMEs to make financial reports, in Law Number 20 Article 23 of 2008 mentions the role of government, namely (1) Improving access of Micro and Small Enterprises to financing sources through the Government and Local Government (a) growing, developing, and expanding the network of non-bank financial institutions; (b) Fostering, developing, and extending the reach of credit guarantee institutions; and (c) Provide convenience and facilitation in meeting the requirements to obtain financing. (2) The business community and the community participate actively in improving micro and small business access to loans or credits as well as (a) improving the ability to prepare business feasibility studies; (b) increasing knowledge of credit or loan application procedures; and (c) enhancing technical and managerial understanding and technical skills.

The government through its role as a catalyst must be able to cultivate the spirit of entrepreneurship by having creative and innovative behavior on SMEs as the main capital to compete. According to the Ministry of Tourism and Creative Economy (2014), the main resource in the creative economy is creativity that is defined as the capacity or ability to produce or create something unique, creating solutions of a problem, or doing something 
different by thinking outside the box. Then, the concept of theory used in research to measure the role of government improves the performance of SMEs into creative SMEs using (1) Law Number 20 of 2008 that becomes the indicator in this research to measure the role of Government from training, business climate, capital matter, and marketing matter (2) Piterou \& Birch (2014) conducted technology transfer (3) theoretical concepts used to measure the creativity of SMEs using the concept of the Ministry of Tourism and SMEs (2014) which measures the level of creativity of SMEs to create uniqueness or different products with competitors.

\section{Thinking Flow Framework}

The condition of Small and Medium Industries is always assessed with conditions that are difficult to develop, but only able to survive or even becoming out of business. The problems that generally arise are from the internal and external environment of the SMEs. The internal problem illustrated the ability of the SMEs itself to produce products which are still low, especially on the quality of human resources to produce products of interest to the market. The solution to improving the ability of SMEs is the role of government through policies of program delivery, so that internal problems, such as low quality of human resources, capital problems, and inability to create products according to market taste can be overcome. Based on the concepts from the experts and previous research, the framework of thought in this research can be illustrated in Figure 1.

\section{MeThoD}

The variables studied in this research are the role of government and SMEs creativity, the role of government is a set of behaviors expected by others of someone with a certain status, the measurement of the government's role by referring to Law Number 20 of 2008, Piterou \& Birch (2014) which measures the role of the Government through 7 (seven) indicators. The second variable studied is the SMEs creativity, which is the capacity or ability to produce or create something unique (Ministry of Tourism and Creative Economy, 2014) that gratify creativity through 3 dimensions. The study was conducted in 7 (seven) districts, the basis of the district is based on topography, which divides the west, the middle, and the east. The selected SMEs are the handicraft, culinary, and fashion sectors, the basis for the selection of these three sectors is they are able to contribute greatly to Jambi Province. The selected sample is 200 respondents. The sampling technique for the respondents in a purposive sampling and the samples taken already meet the criteria that have been determined. Data collection is conducted by spreading questionnaire, interview, observation, and literature study. The type is closed questionnaire, in which the respondents' answers are directed and they just have to choose as perceived by the respondents. The data analysis is done by descriptive analysis, which describes the role of government in boosting the performance of SMEs towards creative SMEs. The measurement of parameters in descriptive analysis uses a range of scales, which is thelinkert and Gutman scales. Linkert scale to see the condition of variables in the form of categories described in the role of government, which is not good, not good enough, good enough, good and very good. With the calculation as follows:

$$
\mathrm{RS}=(\mathrm{m}-1) / \mathrm{m}
$$

Where:

RS $=$ Scale Range

$\mathrm{m}$ = The number of item alternative answer so that:

$$
\mathrm{RS}=((5-1)) / 5=0.8
$$

Specify Categorization for Likert Scale

\begin{tabular}{cc} 
Value & Categorization \\
$1-1.7$ & $\begin{array}{c}\text { Really Low/Really Poor/ } \\
\text { Really Not Optimal }\end{array}$ \\
\hline $1.8-2.5$ & Low/Poor/Not Optimal \\
\hline $2.6-3.3$ & $\begin{array}{c}\text { Enough/Medium/Quite } \\
\text { Optimal }\end{array}$ \\
\hline $3.4-4.1$ & High/Good/Optimal \\
\hline $4.2-5$ & Really High/Really Good/ \\
Really Optimal
\end{tabular}

To categorize SMEs creativity using Guttman scale with creativity category that is not yet good and creativity that is good.

Scale Range for Guttman Scale

$$
\mathrm{RS}=((2-1)) / 2=0.5
$$

Specify Categorization

\begin{tabular}{cc} 
Value & Categorization \\
\hline $1-1.5 \%$ & Creativity is not yet good \\
\hline $1.6-2 \%$ & Creativity is good \\
\hline
\end{tabular}

Before the data of the research questionnaire is analyzed further, firstly tested the validity and 
Table 2.

The Role of Local Government of Jambi in Improving the Performance of SMEs in Jambi Province

\begin{tabular}{|c|c|c|c|c|}
\hline No. & Measuring Items & $\begin{array}{l}\text { Total } \\
\text { Score and } \\
\text { Execution } \\
\text { Achievement }\end{array}$ & Average & Remarks \\
\hline 1 & $\begin{array}{l}\text { The government provides } \\
\text { educational means and } \\
\text { training }\end{array}$ & $\begin{array}{r}436 \\
44 \%\end{array}$ & 2.18 & $\begin{array}{l}\text { (Less good category) there are } \\
\text { still little SMEs that can feel } \\
\text { education and training provided } \\
\text { by the government }\end{array}$ \\
\hline 2 & $\begin{array}{l}\text { The government provides } \\
\text { easy access to information for } \\
\text { the development of business } \\
\text { development }\end{array}$ & $\begin{array}{r}662 \\
66 \%\end{array}$ & 3.31 & $\begin{array}{l}\text { SMEs is good enough to } \\
\text { take advantage of access to } \\
\text { information }\end{array}$ \\
\hline 3 & Conducive business climate & $\begin{array}{r}691 \\
69 \%\end{array}$ & 3.46 & $\begin{array}{l}\text { The business climate is already } \\
\text { conducive }\end{array}$ \\
\hline 4 & $\begin{array}{l}\text { Government helps to market } \\
\text { products }\end{array}$ & $\begin{array}{r}481 \\
48 \%\end{array}$ & 2.41 & $\begin{array}{l}\text { The role of government is less } \\
\text { than optimal in marketing the } \\
\text { product }\end{array}$ \\
\hline 5 & $\begin{array}{l}\text { Receive funding support from the } \\
\text { government }\end{array}$ & $\begin{array}{r}331 \\
33 \%\end{array}$ & 1.65 & $\begin{array}{l}\text { Unfavorable category (SMEs) have } \\
\text { not obtained ease of financing }\end{array}$ \\
\hline 6 & $\begin{array}{l}\text { The government and universities } \\
\text { have conducted transfer } \\
\text { technology }\end{array}$ & $\begin{array}{r}375 \\
38 \%\end{array}$ & 1.88 & Government is less optimal \\
\hline 7 & $\begin{array}{l}\text { The government plays an active } \\
\text { role in developing business }\end{array}$ & $\begin{array}{r}469 \\
47 \%\end{array}$ & 2.35 & Government is less optimal \\
\hline \multicolumn{2}{|c|}{$\begin{array}{c}\text { The role of the Government in growing } \\
\text { creative }\end{array}$} & $49 \%$ & 2.46 & Government is less optimal \\
\hline
\end{tabular}

Source: Respondents (data processed, 2016)

reliability of the measuring instrument to prove whether the measuring instrument used has validity and reliability to measure what should be the measuring function, such as to test whether the questionnaires have carefully and precisely measured what they want to measure in this study.

\section{RESULTS AND DISCUSSION}

\section{A. Testing of Research Instruments}

There are two forms of instrument testing in the research, namely validity test and reliability test. Validity test is done to see whether or not each instrument used in research variables is valid. In accordance with the results of primary data analysis, then each instrument used in this study has a test result that shows that the value of Sig.corelation $<\alpha$ (5\%), which means that all the variables used in the research instrument are valid. For the reliability of research instruments, it is conducted by considering the magnitude of reliability coefficients. In accordance with the results of primary data analysis, each instrument used in the study has test results showing that the Cronbach Alpha is above 0.6. Thus, with the reliability test results, it can be said that all the variables used in this study are reliable.

\section{B. The Role of Government in Improving the Performance of Small and Medium Industry towards Creative Industry}

The government as the regulator, facilitator, and catalyst and perform the function of Supervision on the development of Small and Medium Industry in Jambi Province is a cornerstone to strengthen the existence of Small and Medium Industry in the face of globalization. Currently, the role of the government has not been so strong in growing SMEs towards SMEs that can compete through creativity. The results of the data in Table 2 illustrate the role of government in the performance of Small and 
Medium Industry in Jambi Province.

Table 2 illustrates the role of government in improving SMEs performance. Based on the results of respondents' answers on the role of government through government support in improving the performance of SMEs, it is not optimal as SMEs still feel the support of the government is still lacking, among others:

1. The role of the government in providing educational and training facilities, based on the respondents' answers, only about 44\% of SMEs in Jambi Province that has received education and training for the development of their potential. Still, about $56 \%$ have not been touched by government programs in an effort to improve the ability of SMEs through education and training. The research findings from the survey results explain that the government has not evenly reached the existence of SMEs. This is because the education and training programs are undertaken by the government, both the municipal government and the district government, have not been evenly disseminated, and are encountered by many trainees and educational participants, followed by the same people in each different training activity. This shows the Regional Device Unit (SKPD), which is the leading sector in The Department of Industry and Trade, does not yet have a database of SMEs which have followed the training or which have not followed and what type of training has been followed, thus education and training can be provided equitably. Through education and training, SMEs skills and capability can be realized so that SMEs will grow towards creative SMEs. It supports the research results of Mulolli, Islami, \& Skenderi (2015) which explains that the Company's performance can be achieved through continuous improvement of human resources by providing training and education.

2. The marketing of existing SMEs products in Jambi Province is that only about $48 \%$ already have a market, and the rest $52 \%$ claims to still have no market, they are confused to find a market for their products. The limitations of SMEs knowledge, especially about marketing, cause problems, where most SMEs are only able to make products but cannot sell products. Here, the government must develop a strategy of how the SMEs can have a market for their products. Law Number 20 of 2008 has explained the role of government in helping solve the problem of SMEs marketing by forming partnership pattern. In a partnership pattern, it creates the mainstreaming of products. Generally, for the handicraft, culinary, and fashion sectors have conducted the pattern of general trading partnership, which is to help build marketing cooperation between big and small companies where SMEs function as the supplier. In the general pattern of public trading partnership, the government also plays a role in searching the market through promotional events. Now the concept of partnership has not been run in accordance with the partnership concept. The government's role in its regulation harmonizes big corporations and small firms, so large corporations are willing to support small companies.

3. Government's support in terms of venture capital. The fund is still a major issue for SMEs. SMES still find it difficult to get fund for business development because SMEs do not have Cable Bank yet. Disbursement of fund from the government in the People's Business Credit (KUR) also got the problem. The results of this study explain about $33 \%$ of SMEs which feel they have received funding support from the government in the form of credit with low-interest rates through local government programs and banking institutions, the rest of $67 \%$ find it difficult to get a loan. The average number of SMEs admitted to having difficulty obtaining loans for collateral reasons, while SMEs do not have assets to guarantee. The results of research by Wuryandani \& Meilani (2013) support the results of this study which explains that the of total number of SMEs in Yogyakarta, 90 percent of them are micro business actors who still have difficulties in getting capital assistance as well as marketing strategies and practices. Therefore, they tend not to develop, even often become out of business or change the type of business in accordance with current market trends to survive. The results of this study also match the results of research from Ramdhansyah \& Silalahi (2013) that explain the difficulty of obtaining financing from banks in the absence of collateral, complicated credit procedures, and the attitude of Bank caution in providing credits. One of the bank requirements is that SMEs should have a bookkeeping that describes the company's profit. There are still many SMEs in Jambi Province which has not made bookkeeping about their business, and still, combine the use of personal money and company money. So the outflow of money is not well controlled and eventually run out of capital because it is used for personal needs. The average budget owned is small, consequently, the company is often forced to divide the fund to finance various needs as efficiently as possible and it has an impact on 
Table 3.

The Achievement of SMEs Creativity Level in Jambi Province

\begin{tabular}{|c|c|c|c|c|}
\hline No. & $\begin{array}{l}\text { SMEs Creativity in Producing } \\
\text { Products Different with Other } \\
\text { Products }\end{array}$ & $\begin{array}{l}\text { Total } \\
\text { Score and } \\
\text { Achievement } \\
\text { Level of } \\
\text { Creativity }\end{array}$ & Average & Remarks \\
\hline 1 & $\begin{array}{l}\text { Find a new process or way of } \\
\text { making the prod-uct }\end{array}$ & $\begin{array}{r}293 \\
21.6 \%\end{array}$ & 1.46 & $\begin{array}{l}\text { SMEs creativity level is in the } \\
\text { category of not yet good }\end{array}$ \\
\hline 2 & $\begin{array}{l}\text { Able to find new raw mate-rial } \\
\text { alternatives to improve product } \\
\text { quality }\end{array}$ & $\begin{array}{r}241 \\
17.8 \%\end{array}$ & 1.21 & $\begin{array}{l}\text { SMEs creativity level is in the } \\
\text { category of not yet good }\end{array}$ \\
\hline 3 & $\begin{array}{l}\text { Creating products that are } \\
\text { different from the previous } \\
\text { products and have a better } \\
\text { function of the previous products } \\
\text { (for culinary has a better taste, } \\
\text { healthier if consumed) }\end{array}$ & $\begin{array}{r}326 \\
24.1 \%\end{array}$ & 1.63 & $\begin{array}{l}\text { SMEs creativity level is in the } \\
\text { category of not yet good }\end{array}$ \\
\hline 4 & $\begin{array}{l}\text { Ever make a product, in which } \\
\text { its raw material is more efficient } \\
\text { than previous product (for } \\
\text { culinary, the process of making } \\
\text { is faster and more efficient in } \\
\text { raw materials than the previous } \\
\text { product type) }\end{array}$ & $\begin{array}{r}266 \\
19.6 \%\end{array}$ & 1.33 & $\begin{array}{l}\text { SMEs creativity level is in the } \\
\text { category of not yet good }\end{array}$ \\
\hline 5 & $\begin{array}{l}\text { Never produce products that } \\
\text { have differences with competi- } \\
\text { tors by utilizing technology }\end{array}$ & $\begin{array}{r}228 \\
16.8 \%\end{array}$ & 1.14 & $\begin{array}{l}\text { SMEs creativity level is in the } \\
\text { category of not yet good }\end{array}$ \\
\hline \multicolumn{2}{|c|}{$\begin{array}{l}\text { The average achievement of SMEs creativity } \\
\text { produces products that are different than } \\
\text { other products }\end{array}$} & $\begin{array}{r}1,354 \\
19.98 \%\end{array}$ & 1.35 & $\begin{array}{l}\text { SMEs creativity level is in the } \\
\text { category of not yet good }\end{array}$ \\
\hline
\end{tabular}

Source: Respondents (Data Processed, 2016)

business operational matters so that there is a lack of business capital (Saragih \& Surikayanti, 2015).

4. The number of SMEs in Jambi Province which receive technological development is still little, only about 38\% (business actors from the handicraft, culinary, and fashion sectors) in producing goods that already use technology. For example, for the handicraft and fashion sectors using machines that work faster and neater than the manual, as well as the culinary sector. SMEs from the sector of handicraft, culinary, and fashion have been utilizing the development of technology for market disposal so as to have a wider market share. This is very good, as SMEs are able to increase the workforce so that unemployment can be reduced. However, in Jambi province, there are still many SMEs that have not received technological support from the government of about $62 \%$, because the government program to build SMEs capacity has not been done thoroughly, there are still many unreached or untouched SMEs to receive education and training programs.

5. The role of the government in developing the business, based on research findings from the results of the data processing the government's role in developing the SME group business is in the less good category that only about $47 \%$ feel that the government has helped develop their business. The government's supports are in the form of providing capital assistance, hosting events, and promoting SMEs products. Approximately 53\% consider the government has not helped develop their business, both in terms of capital assistance and other things related to their business. 
But the role of the government is good enough to create a conducive business climate, and to provide access to information on the ease of the process of marketing and product distribution. According to business actors, the government has helped enough in providing infrastructure for easy access, it is proven with about $66 \%$ of business actors who feel good enough in experiencing the ease of access to information provided by the government, both through the related industry and trade agency and stakeholders.

The role of the government in creating a conducive climate for SMEs is good enough, in which about $69 \%$ of business actors have stated that the government has provided a conducive climate through the regulations, set forth in the Law Number 20 of 2008. The conducive climate is depicted on government obligations and business actors' obligations. The Government carries out the obligation to empower SMEs and facilitates business licenses and is related to business smoothness. The obligations of business actors are to pay taxes, pay attention to environmental sustainability, and comply with the provisions on manpower. Approximately 31\% of SMEs in Jambi Province still assume that the government has not yet created a conducive climate, based on the findings from the results of the respondents' answers that it is still difficult in terms of intellectual property rights (IPR) on their products, and there are even business actors who do not understand at all about Intellectual Property Rights. This is due to socialization and appeals by the government to protect the work of SME actors that has not been implemented maximally.

The problem faced by SMEs in Jambi Province, especially the internal problem, is the ability of Human Resources in Managing the company's management so that the business conducted to get profit is still weak. The lack of government support in building the capacity of SMEs in Jambi Province (handicraft, culinary and fashion sectors) has made it difficult for SMEs to follow the dynamics of market needs. SMEs have not been able to present products that are ready to compete with changes or different products with competitors so as to attract consumers to buy. The findings of the field on the ability of SMEs from the handicrafts, culinary, and fashion sectors to produce products lead to differences with competitors in terms of taste, appearance, and quality can be explained in Table 3 .

Table 3 illustrates the achievement of SMEs creativity level in Jambi Province in producing products that have uniqueness and the difference is in the category that is not yet good. This will have an impact on SMEs marketing itself. The results of this study are in line with Uchegbulam et al.'s research (2015), which conducted a research on 150 SMEs in the Sululere region in Nigeria, the result proves that market share will decrease if SMEs are unable to produce products that have the difference and uniqueness that are favored by consumers.

\section{The Role of Local Government in Improving the Performance of Small and Medium Industry Towards Small and Medium Creative Industry in Jambi Province}

The findings of this study described in Table 2 can be concluded that the role of government is not optimal in solving the problems of SMEs, government's support to improve the performance of SMEs is only about 49\% (see Table 2), thus impacting on the ability of SMEs to produce products that have selling value. Based on this, the government needs to increase its role through its policy to improve the performance of SMEs, so that SMEs can improve its existence by building the capacity of SMEs in a sustainable manner.

SMEs performance improvement by government is implemented through the SMEs Empowerment program that has been stated in Law Number 20 of 2008 should be implemented in harmonization and integrated between the Regional Work Unit (SKPD) associated with SMEs. SKPD that is responsible for the management of SMEs and acts as a leading sector is the Department of Industry and Trade. The types of empowerment programs that have been undertaken by the Department of Industry and Trade are providing educational and training, assisting promotional efforts, and helping to expand the market by building partnerships.

Meanwhile, other Regional Work Units such as Department of Cooperatives and SMEs, and the Tourism Office also performs some similar activities, such as training and education, marketing activities through promotional events, following the bazaar, exhibiting in both local and outside areas, that it causes program overlap. While the achievement or target of each SKPD has not been able to improve the performance of SMEs to compete. Overlapping of similar activities in the field of training will result in unevenness of SMEs getting training because each SKPD conducting training has not had a database of SMEs and has not built synergistic between SKPD.

Therefore, it is necessary to create policies that harmonize and synergize work programs among related SKPD to build the capacity of SMEs in improving its performance. Every program of the same nature needs to be integrated into the related SKPD and mapping activities, so the spillover activity does not happen and the ultimate goal can be achieved.

The low level of creativity achieved by SMEs of about 19.98\% (see Table 3) in Jambi Province should be the main priority of the local government 
agenda sustainably on strengthening the capacity of SMEs, thereby growing SMEs that have a creative soul in producing goods and services. The low level of creativity is due to the ability of SMEs to improve their quality to receive knowledge and technological development is still low, as evidenced by about $44 \%$ of IKM (see Table 2) newly participated in education and training programs. One of the keys to the success of SMEs is to have quality human resources gained through education and training so as to utilize and follow technological developments.

The progress of civilization triggers lifestyle changes, technology has colored human life, and therefore to follow the development of consumer appetite business actors (business world) is a must to always follow the development of science and technology. Therefore, the government as a Facilitator should facilitate the transfer of knowledge and transfer of technology by cooperating with universities. The innovator actor (inventor) of science and technology is the University. For that, the government builds cooperation with universities to transfer knowledge and technology that will be applied by business actors (business world) known as triple helix. The results of Soekarno (2013) make it clear that triple helix can increase the creativity of SMEs so that SMEs grows into Creative SMEs. The results of Asyhari \& Wasitowati (2015) also make it clear that triple helix can improve performance through the growth of creativity among business people.

\section{Conclusion}

The role of the Government to improve the performance of SMEs towards creative SMEs in Jambi Province has not been optimally implemented. Government support is still low in the field of quality improvement of Human Resources through the provision of education and training, the Department of Industry and Trade as the leading sector, does not have a database that informs what types of training have been given to SMEs groups, so that education and training cannot be applied equally. SMEs still have problems to get business capital loan, the government's attention to SME to introduce technological progress is less than optimal and not yet optimal to assist product development and product marketing. The government's program policy in fostering SME's creativity into creative SME has not been implemented in synergy, there are still some SKPD related to SME empowerment to do the same program so that the target to grow SME's creativity into creative IKM is not achieved. In terms of business climate that is already conducive, the government provides easy permits related to the smooth of operation.

\section{SUGGESTION}

The government needs to improve its role in improving the quality of Human Resources in SMEs by providing education and training equitably; therefore, the Department of Industry and Trade needs to create a database that contains information about participants who have attended the training and the type of training that is followed, so that the same types of training can be given to other participants. To overcome the lack of capital and SMEs who do not yet have a Cabling Bank, the government needs to develop microfinance institutions as a solution to overcome the capital difficulties for SMEs, the role of government in the regulation of harmonization between large companies and small companies, so large companies are willing to help the marketing of small companies by building partnership patterns, Jambi Provincial Government needs to build cooperation with university as actor innovator and involves business as user and its leading sector is R\&D Agency in province/city/regency.

\section{ACKNOWLEDGEMENT}

The author expressed his gratitude to Balitbangda Jambi Province which has provided fund in this research. Department of Industry and Trade, Department of Cooperatives, and MSMEs and Department of Tourism that has assisted the implementation of the research activities so that this research can be completed properly.

\section{REFERENCES}

Asyhari, \& Wasitowati. (2015). Hubungan Triple Helix, Inovasi, Keunggulan Bersaing dan Kinerja. In 2nd Conference in Business, Accounting, and Management (pp. 320-334). Sultan Agung Islamic University.

Gjini, K. (2014). Small and Medium Sized Enterprises; Growth Factors. ESJ, 1. Retrieved from http://eujournal.org/index.php/esj/ article/view/2818

Harash, E., Al-Timimi, S., \& Alsaadi, J. (2014). The Influence of Finance on Performance of Small and Medium Enterprises (SMES). International Journal of Engineering and Innovative Technology (IJEIT), 4(3), 161-167. http://doi. org/10.12735/jbm.v3i4p48

Indarti, I., \& Anton. (2014). Tantangan Usaha Mikro Kecil dan Menengah dalam Menghadapi ASEAN Economic Communtiy 2015. In 3rd Economics Business Reasearch Festival (Vol. 3, pp. 10131028). FEB-UKSW.

Ismail, K., Zaidi, W., Omar, W., Soehod, K., Senin, A. A., \& Akhtar, C. S. (2014). Role of Innovation in SMEs Performance : A Case of Malaysian SMEs. In Mathematical Method in Engineering and 
Economics (pp. 145-149). Prague.

Law of the Republic of Indonesia Number 20 of 2008 on Micro, Small and Medium Enterprises, Pub. L. No. 20 (2008). Indonesia.

Maryati, W. (2012). Peran Perguruan Tinggi dalam Pemberdayaan Entrepreneurship untuk Mengembangkan Wirausahawan Kecil Menghadapi Persaingan Global. Prosiding Seminas Competitive Advantage, 1(2). Retrieved from http://journal.unipdu.ac.id/ index.php/seminas/article/view/144

Ministry of Tourism and Creative Economy. (2014). Ekonomi Kreatif: Kekuatan Baru Indonesia Menuju 2025. Ministry of Tourism and Creative Economy.

Mulolli, E., Islami, X., \& Skenderi, N. (2015). Human Resource Management Practices and SMEs Performance: Study Based in Kosovo. International Review of Management and Business Research, 4(4).

Ntiamoah, E. B., Li, D., \& Kwamega, M. (2016). Impact of Government and Other Institutions' Support on Performance of Small and Medium Enterprises in the Agribusiness Sector in Ghana. American Journal of Industrial and Business Management, 6, 558-567. http://doi. org/10.4236/ajibm.2016.65052

Piterou, A., \& Birch, C. (2014). The Role of Higher Education Institutions in Supporting Innovation in SMEs: University-based Incubators and Student Internships As Knowledge Transfer Tools. InImpact: The Journal of Innovation Impact, 7(1), 72-79. Retrieved from http:// nimbusvault.net/publications/koala / inimpact/298.html

Quaye, I., \& Sarbah, A. (2014). Assessing Alternative Sources of Financing for Small \& Medium Scale Enterprises in Ghana: Case Study of Savings and Loans Companies (S\&Ls) in the Greater Accra Region of Ghana. International Journal of Advancements in Research \& Technology, 3(7), 123-136. Retrieved from http://www.ijoart. org/research-paper-publishing_july-2014. shtml

Raliby, O., Rusdjijati, R., \& Prabowo, N. A. (2013). Standarisasi Produk Guna Meningkatkan Daya Saing IKM Mainan Anak di Kota
Magelang. In Simposium Nasional Teknologi Terapan (SNTT) 2013 (pp. 41-47). Retrieved from https://publikasiilmiah.ums.ac.id/ handle/11617/4112

Ramdhansyah, \& Silalahi, S. A. (2013). Pengembangan Model Pendanaan UMKM Berdasarkan Persepsi UMKM. Jurnal Keuangan \& Bisnis, 5(1). Retrieved from http://siastie. harapan.ac.id/jurnal/index.php/JKB/article/ view/106

Saragih, F., \& Surikayanti. (2015). Analisis Penerapan Akuntansi dan Kesesuaiannya dengan SAK ETAP pada UKM Medan Perjuangan. In Seminar Nasional Ekonomi Manajemen dan Akuntansi (SNEMA) Fakultas Ekonomi Universitas Negeri Padang (pp. 452-461). Padang: Universitas Negeri Padang.

Soekarno, G. (2013). Pertumbuhan Industri Kreatif di Surabaya Melalui Upaya Triple Helix dan Keunggulan Bersaing. In Seminar Nasional dan Sidang Pleno ISEI XVI: Mempercepat Penguatan Daya Saing Ekonomi Daerah Menghadapi Masyarakat Ekonomi ASEAN 2015 (pp. 212224). Jambi: Pengurus Pusat Ikatan Sarjana Ekonomi Indonesia.

Sudiarta, I. P. L. E., Kirya, I. K., \& Cipta, I. W. (2014). Analisis Faktor-faktor yang Mempengaruhi Kinerja Usaha Mikro Kecil dan Menengah (UMKM) di Kabupaten Bangli. E-Journal Bisma Universitas Pendidikan Ganesha, 2(1), 11-21. Retrieved from http://ejournal.undiksha. ac.id/index.php/JJM/article/view/3381

Uchegbulam, Princess, Akinyele, Samuel, Ibidunni, \& Ayodotun. (2015). Competitive Strategy and Performance of Selected SMEs in Nigeria. International Conference on African Development Issues (CU-ICADI) 2105: Social and Economic Models for Development Track, 326-333.

Wuryandani, D., \& Meilani, H. (2013). Peranan Kebijakan Pemerintah Daerah dalam Pengembangan Usaha Mikro, Kecil, dan Menengah di Provinsi Daerah Istimewa Yogyakarta. Jurnal Ekonomi Dan Kebijakan Publik, 4(1), 103-115. http://doi. org/10.22212/jekp.v4i1.71 